\title{
RESEARCHPAPER
}

\section{Antibacterial effect of green tea on oral bacterial species}

\author{
NOOPUR MISHRA AND O.P. VERMA \\ Department of Molecular and Cellular Engineering, Jacob School of Biotechnology and Bio-Engineering, Sam \\ Higginbottom Institute of Agriculture, Technology and Sciences, ALLAHABAD (U.P.) INDIA \\ Email : om.verma@shiats.edu.in
}

Article Info :Received : 10.12.2015; Revised : 15.01.2016; Accepted : 9.02.2016

In the present study the samples were collected from mouth for isolation of bacterial species using spreading and streaking techniques. The isolated bacterial species were identified by performing various biochemical tests. Different extracts of green tea were prepared in different solvents like ethanol, methanol, propanol of different concentrations to check the antibacterial activity of green tea on bacteria isolated from mouth. The maximum zone of inhibition was observed in green tea (Tetley) extract in methanol 90 per cent $(3.5 \mathrm{~cm})$ and minimum was observed in propanol 30 per cent $(1.4 \mathrm{~cm})$ in Tetley green tea. Thus, from present study it was found that the green tea extracts exhibited remarkable antibacterial properties. The green tea extract helped in destroying the pathogenic bacteria present in mouth, thus preventing diseases.

Key words : Green tea, Inhibition zone, Antibacterial activity, Biofilm

How to cite this paper : Mishra, Noopur and Verma, O.P. (2016). Antibacterial effect of green tea on oral bacterial species. Asian J. Bio. Sci., 11 (1) : 95-99 [Special Issue of AFBSAH-2016]. 